\title{
Determinants of Work Life Balance Among Women in Chennai City
}

\author{
C. P. Senthil Kumar, H. Krupanandhan
}

\begin{abstract}
This empirical study focuses on determinants of work life balance of women in Chennai city of Tamil Nadu. The exploratory research design with primary data method was adopted to gather information from four hundred women residing in Chennai city. The statistical tools such as, percentage analysis and multiple linear regression analysis have been applied to explore the meaningful findings to the research objectives. The result indicates that coping strategies, organisational support, familial support and job description have significant influence on the work life balance of women in Chennai city of Tamil Nadu. This research study proves that job description as an important aspect determines the work life balance which indicates there is need to understand the role and responsibilities of the individual in an organisation to achieve and accomplish the organisational goals of the organisation.
\end{abstract}

Keywords : Work Life Balance, Women, Job Description, Organisational Support and Family Support.

\section{INTRODUCTION}

$\mathrm{T}_{\mathrm{o}}$ oday's employees are highly exposed to work life imbalance in their professional and personal life due to many imperative reasons. The human resource managers are highly working on these areas to provide innovative and ideological solutions to the work life imbalance among employees. Employees are not having quality time with their family members due to several work pressure and lack of time and on the other hand, they face lot of problems to achieve higher productivity or targets in their organisation. These two important aspects are highly causing the employees to experience higher occupational stress in their professional life. There is a need to explore the factors and dimensions that contributes for the work life balance in competitive, pressure and complex organisational environment. Especially, women employees are facing as many as problems such as, lack of familial and organisational support, lesser job satisfaction, unclear job description etc., in their day-to-day life.

Revised Manuscript Received on December 05, 2019.

* Correspondence Author

Dr. C.P. Senthil Kumar, Assistant Professor and Research Supervisor, P.G and Research Department of Commerce, Guru Nanak College (Autonomous), Chennai - 600 042, Tamil Nadu - India

H. Krupanandhan*, Ph.D. Research Scholar, P.G and Research Department of Commerce, Guru Nanak College (Autonomous), Chennai - 600 042, Tamil Nadu - India, Email ID: krupahari1992@gmail.com

\section{REVIEW OF LITERATURE}

Suboosh Yusuf (2018) has conducted comparative study of work life balance and its impact on employee job satisfaction among BPO employees of Aligarh and Delhi. The researcher developed hypothesis to identify the difference among gender of the employees with respect to their perception on work life balance and job satisfaction. The researcher collected primary information from two hundred BPO employees and the information collected were subjected to independent sample ' $\mathrm{t}$ ' test by using SPSS. The results indicate that there is no difference of opinion between male and female employees with respect to their job satisfaction and work life balance.

Deivasigamani and Shankar (2017) conducted an exploratory study with primary objective of exploring the problems prevailing among information sector women employees on their work life balance maintenance. The researcher found that, improper work environment, lack of superior and subordinate relationship, unhealthy interpersonal relationship, occupational challenges and psychological issues are major problems of women employees in IT sector of Chennai City. Further the researchers suggested the organisation to encourage women empowerment, workers participation in management, effective leadership and job enrichment to enhance the work life balance.

Chetan Arora and RajlakshmiWagh (2017) educated the importance of work life balance for the wellness of the various business organisation. The authors stated the importance of work life balance to effectively execute the work life responsibilities. The authors finally concluded that, work life imbalance will lead to absenteeism, stress and job dissatisfaction.

Mrinalini Pandey (2016) conducted a study to examine the impact of work life balance on job satisfaction of women doctors of private hospitals of Jharkhand City. The structured questionnaire was used to collect data from one hundred and fifteen women doctors by adopting survey method through non-random convenient sampling technique. The empirical evidences explicit that, higher is the age higher is the wok life balance and job satisfaction. Work life balance and coping strategies have significant and positive influence one job satisfaction of women doctors of private hospitals.

Published By:

Blue Eyes Intelligence Engineering 
Finally, the authors suggested the women doctors to avoid the professional works at home and vice versa to maintain better work life balance.

Vijay Anand (2016) carried an empirical research to explore the rural employees work life balance. The researchers have tried to explore the association between various demographic variables and work life balance. The primary data were collected through structured questionnaire from one hundred and twenty employees by employing simple random sampling technique. The result of chi-square test indicates that age, gender, monthly income and level of employment have significant association with work life balance. Finally, the authors concluded that work life balance helps the rural employees to enhance their level of productivity.

Ponnampalam (2012) have made an empirical investigation on work life balance of telecom employees to identify the role of emerging HRM interventions. This research study was conducted with the primary purpose of exploring the significance of HRD policies and procedures for the betterment of work life balance among telecom employees. The researchers employed structured questionnaire to collect information from two hundred and thirty respondents by adopting survey method of data collection. The result indicates that, HRD practices have significant positive influence on the work life balance and they also suggested the organisation to take necessary steps to reduce stress which is a major cause for work life imbalance.

Vishwa Nath Maurya and et.al (2015) have carried descriptive research study to examine the impact of work life balance policies on job satisfaction of the employees in banking sector. The primary data collected from two hundred and forty bank employees are subjected to multivariate correlation and regression analysis to test the causal effect. The result indicates that work life balance policies such as, flexibility leave provisions, welfare policies and job design have significant relationship with each other and all these policies are significantly and positively influencing the job satisfaction among the employees in Indian banking sector. Further the researchers also educated the imperativeness of job satisfaction for the enrichment in performance of the financial institutions.

Sachiko Makabe and et.al (2015) investigated the impact of work life imbalance on quality of work life and job satisfaction of nurses in Japan. The researchers adopted cross-sectional surve method to collect primary information from one thousand two hundred and two Japanese hospitals and they divided them into four groups. The result shows that actual work life balance is lesser compared to desired work life balance. Further, the authors proved that work life imbalance is significantly influencing the job satisfaction and quality of work life and they suggested to offer diverse pattern of work, job security and awareness creation to increase quality of care and overall health of the Japanese acute care hospital nurses.

\section{STATEMENT OF THE PROBLEM}

Women employees and women entrepreneurs are experience major problems in the society due to gender discrimination and other factors. Work life balance is a very imperative concept need to be focused to have better job satisfaction and job commitment among the employees and self-employed women in India. There is a need and importance to explore the various determinants of work life balance of women in the 21 st century. This study aims to answer and explicit the various determinants of the work life balance.

\section{RESEARCH OBJECTIVES OF THE STUDY}

This research study aims to explore, the socio-economic characteristics of the women and to explore the determinants of work life balance of women in Chennai city.

\section{RESEARCH METHODOLOGY}

This research study collected primary data using structured questionnaire. The survey questionnaire started with respondents demographic profile and ended with variable specific Questions related to work life balance, coping strategies, occupational stress, family support, organisational support, job description and job satisfaction were asked through a five point Likert scale where 1 stands for "strongly disagree", 5 stands for "strongly agree". The sample size was 400 and convenience sampling technique had been used to collect the primary data from respondents. After the data has been collected, it was processed using SPSS version 23.0 software package for the following analysis.

\section{RESULTS AND DISCUSSION}

The primary data collected from women are subjected to percentage analysis and regression analysis to draw meaningful findings for the research objectives of the study. The demographic characteristics of the respondents are tabulated and inferred in Table 1.

Table 1: Demographic Characteristics of the Respondents

\begin{tabular}{ccc}
\hline Demographic Profile $(\mathbf{N}=\mathbf{4 0 0})$ & Frequency & Percent \\
\hline Nature of the Job & & \\
Public Company & 116 & 29.0 \\
Private Company & 148 & 37.0 \\
Self - Business & 136 & 34.0 \\
Age (In Years) & & \\
25 - 30 Years & 116 & 29.0 \\
31 - 35 Years & 112 & 28.0 \\
36 - 40 Years & 76 & 19.0 \\
41 - 45 Years & 68 & 17.0 \\
Above 46 Years & 28 & 7.0
\end{tabular}


Work Experience (In Years)

$\begin{array}{lll}\text { Below } 10 \text { Years } & 224 & 56.0 \\ \text { Above } 10 \text { Years } & 176 & 44.0\end{array}$

Annual Income (In Rs.)

$\begin{array}{lcc}\text { Below Rs.2 Lakhs } & 184 & 46.0 \\ \text { Rs.2 Lakhs - Rs.5 Lakhs } & 164 & 41.0 \\ \text { Above 5 Lakhs } & 52 & 13.0\end{array}$

Marital Status

Married

Unmarried

Nature of Family

Nuclear

220

55.0

Joint

180
Table 1 indicates that maximum number of respondents working in private companies $(37.0 \%)$ followed by Self-Business (34.0\%) and public companies (29.0\%). Sizeable portion of the respondents are aged between 25 years and 30 years $(29.0 \%)$ followed by, between 31 years and 35 years $(28.0 \%)$, between 36 years and 40 years (19.0\%), between 41 years and 45 years $(17.0 \%)$ and above 46 years $(7 \%)$. Maximum number of respondent are earning less than Rs. 2 Lakhs (46.0\%) as annual income followed by, between 2 Lakhs and 5 Lakhs (41.0\%) and Above Rs. 5 Lakhs (13.0\%). Majority of the respondents are married $(85.0 \%)$ and hailing from nuclear families $(55.0 \%)$.

The multiple linear regression analysis has been applied to understand and explore the determinants of work life balance of women in Chennai city. The results are presented and tabulated in Table 2.

Table 2: Regression Result of Determinants of Work Life Balance of Women Employees

\begin{tabular}{|c|c|c|c|c|c|c|c|c|c|c|}
\hline \multirow{2}{*}{$\begin{array}{l}\text { Dependent } \\
\text { Variable }\end{array}$} & \multirow{3}{*}{ Significant Predictors } & \multirow{3}{*}{$\begin{array}{l}\text { Mean (SD) } \\
\text { 23.980 } \\
(\mathbf{3 . 6 7 6})\end{array}$} & \multirow{3}{*}{$\begin{array}{l}\text { F-Valu } \\
\text { e } \\
\text { 25.064 } \\
(\mathbf{0 . 0 0 0 )}\end{array}$} & \multirow{3}{*}{$\begin{array}{l}\text { R } \\
\text { 0.45 } \\
\text { 0 }\end{array}$} & \multirow{3}{*}{$\begin{array}{c}R^{2} \\
0.202\end{array}$} & \multirow{3}{*}{$\begin{array}{c}\text { Adju } \\
\text { sted } \\
R^{2}\end{array}$} & \multirow{3}{*}{$\beta(t-$ Value $)$} & \multirow{3}{*}{ Sig. } & \multicolumn{2}{|c|}{ Collinearity Statistics } \\
\hline & & & & & & & & & $\begin{array}{c}\text { Toleranc } \\
\text { e }\end{array}$ & VIF \\
\hline $\begin{array}{ll}\text { Work } & \text { Life } \\
\text { Balance } & \end{array}$ & & & & & & & & & & \\
\hline 7 - Items & Coping strategies & $\begin{array}{l}27.540 \\
(3.702)\end{array}$ & & & & & $0.319(6.343)$ & $\underset{*}{<0.000 *}$ & 0.796 & 1.256 \\
\hline 6 & Family Support & $\begin{array}{l}20.020 \\
(3.700)\end{array}$ & & & & & $0.229(4.851)$ & $\begin{array}{c}<0.000 * \\
*\end{array}$ & 0.907 & 1.102 \\
\hline 4 & Job Description & $\begin{array}{l}13.800 \\
(2.022)\end{array}$ & & & & & $\begin{array}{c}-0.138 \\
(-2.943)\end{array}$ & $\begin{array}{c}<0.003 * \\
*\end{array}$ & 0.924 & 1.082 \\
\hline 5 & Organisation Support & $\begin{array}{l}18.420 \\
(3.021)\end{array}$ & & & & & $0.142(2.838)$ & $\begin{array}{c}<0.005 * \\
*\end{array}$ & 0.806 & 1.241 \\
\hline 6 & Occupational Stress & $\begin{array}{l}20.970 \\
(2.609)\end{array}$ & & & & & $0.017(0.356)$ & 0.722 & 0.905 & 1.105 \\
\hline 5 & Job Satisfaction & $\begin{array}{l}19.650 \\
(2.707)\end{array}$ & & & & & $\begin{array}{c}-0.008 \\
(-\mathbf{- 0 . 1 4 8})\end{array}$ & 0.883 & 0.679 & 1.472 \\
\hline
\end{tabular}

Constant with $t$ value of 10.972 at $P$ Value of $<0.001 * *$ - (Ocuupational Stress and Job Satisfaction Dimensions are $s$ not Significant Influencing the Work life balance of women employees) - Overall Cronbach's Alpha Value $==\mathbf{0 . 7 2 8}$ (40 Items)

Notes: *** Significant @ 1\% level, *Significant @ 5\% Level.

Table 2 reveals that OLS Model has a goodness of fit for multiple regression analysis and the linear combination of Coping strategies, family support, job description and organization support is significantly related to Work Life Balance, $\{\mathrm{F}=56.500, \mathrm{p}<0.001\}$. The multiple correlation co-efficient is 0.450 , indicating that $20 \%$ of the variance of the respondent's work life balance in the order of influence, is accounted by linear combination. Coping strategies, family support, job description and organization support significantly and positively influence work life balance of the respondents. Whereas, occupational stress and job satisfaction do not have no significant influence on total work life balance.

\section{IMPLICATIONS AND CONCLUSION}

This study proves that, women employees and women entrepreneurs are lacks in work life balance. The factors such as, personal support, organisational support, job description and coping strategies are highly, significantly and positively influencing the work life balance of the women in Chennai city. Whereas, job satisfaction and occupational stress do not have significant influence on work life balance. So, The private and public sector company management is suggest to focus on coping strategies to reduce work life imbalance among the women to have high commitment and engagement in their professional life along with better maintenance of familial life. This research study proves that job description as a important aspect determines the work life balance which indicates there is need to understand the role and responsibilities of the individual in an organisation to achieve and accomplish the organisational goals of the organisation. 
The right person should be appointed for the right kind of a job and at time in the organisation to match the expectations of individual to match the expectations. Women entrepreneurs should spend quality time with their family members in spite of their busy schedule to have higher work life balance. To conclude, the individuals should be given focus to their personal goals and targets clearly to focus specified work rather than the other additional aspects directly or indirectly connected to work life of individuals.

\section{REFERENCES}

1. Yusuf, S. (2018) A Comparative Study of Work-Life Balance and Job Satisfaction of the Employees Working in Business Process Outsourcing Sector. Sciences (ISSN 2455-2267), 10(2), 87-93.

2. Deivasigamani, J., \& Shankar, G. (2014) A study on worklife balance of employees in information techonolgy (it) sector at chennai. International Journal of Management Research and Reviews, 4(8), 805.

3. Arora, C., \& Wagh, R. (2017) Importance of Work-Life Balance. International Journal of New Technology and Research, 3(6).

4. Pandey, M. (2016). Impact of work-life balance on job satisfaction of women doctors. Problems and Perspectives in Management, 14(2), 319.

5. Vijay, A. (2016). Employee Work-Life Balance-A Study with Special Reference to Rural Employees. Indian Journal of Science and Technology, 9(27), 1-6.

6. Ponnampalam, P. K. (2012). HRM interventions to address work-life balance issues in private institutions of higher learning in Malaysia.

7. Maurya, V. N., Jaggi, C. K., Singh, B., Arneja, C. S., Maurya, A. K., \& Arora, D. K. (2015). Empirical analysis of work life balance policies and its impact on employee's job satisfaction and performance: Descriptive statistical approach. American Journal of Theoretical and Applied Statistics, 4(2-1), 33-43.

8. Makabe, Sachiko \& Takagai, Junko \& Asanuma, Yoshihiro \& Ohtomo, Kazuo \& Kimura, Yutaka. (2014). Impact of work-life imbalance on job satisfaction and quality of life among hospital nurses in Japan. Industrial health. 53(10), 2014-2041.

\section{AUTHORS PROFILE}

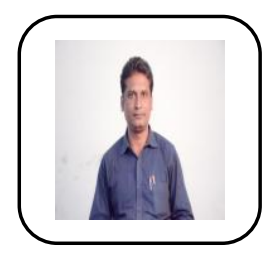

Dr. C. P. Senthilkumar is currently serving as an Assistant Professor in P G and Research Department of Commerce, Guru Nanak College (Autonomous), Chennai. $\mathrm{He}$ is recognized research supervisor guiding doctoral research students leading to the $\mathrm{PhD}$ degrees. He is having more than 20 Years of teaching and research experience in the field of commerce at Post Graduate level. He received Doctoral Degree from Department of Commerce, Annamalai University in the field of finance. He organized various national and international conferences, colloquium and workshops for the betterment of academic fraternity. He participated and presented numerous research papers in various national and international conferences. He contributed many academic writings and contribution to the leading journals in the field of commerce and management. He is panel member and subject expert for the various city colleges in Chennai.

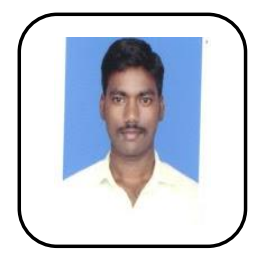

H. Krupanandhan Was full time $\mathrm{PhD}$ Research Scholar in PG and Research Department of Commerce, Guru Nanak College (Autonomous), Chennai. He is pursing doctoral research in the field of Human Resource Management and Skill Development. He received Under-Graduation, Post Graduation and Pre Doctoral Research Programme's were awarded from University of Madras, Chennai. He is an active researcher in participating various national and international conferences and workshops across the country. 